Article

\title{
An Empirical Analysis on DPRK: Will Grain Yield Influence Foreign Policy Tendency?
}

\author{
Chi Zhang ${ }^{1,3,+}$, Jun $\mathrm{He}^{2,3, *,+}$ and Guanghui Yuan ${ }^{4, *,+} \mathbb{D}$ \\ 1 School of Government, Shanghai University of Political Science and Law, Shanghai 201701, China; \\ 12110170023@fudan.edu.cn \\ 2 Shanghai Research Center for Students' Safety Education, Shanghai 200032, China \\ 3 Kunming New Times Research Institute for the Protection of Oversea Interests and Security Studies, \\ Kunming 650500, China \\ 4 Fintech Research Institute, School of Information Management and Engineering, Shanghai University of \\ Finance and Economics, Shanghai 200433, China \\ * Correspondence: qianchangping@ecust.edu.cn (J.H.); guanghuiyuan@outlook.com (G.Y.); \\ Tel.: +86-21-3922-7387 (G.Y.) \\ + All the authors contributed equally to this work.
}

Received: 19 February 2020; Accepted: 18 March 2020; Published: 30 March 2020

check for updates

\begin{abstract}
Democratic People's Republic of Korea is the hub of Northeast Asia and its geopolitics is of great significance, whose foreign policy trend is not only related to the peace and stability of the region, but also one of the major variables affecting cooperation in Northeast Asia. According to the data on North Korea's grain yield collected by the Korea National Statistical Office, supplemented by the data on international food aid to North Korea collected by the World Food Programme, and combined with the judgment of 10 experts from China, South Korea and the United States on the Hawk and Dove Index of North Korea's foreign policy from 1990 to 2018, we use empirical mode decomposition wavelet transform data analysis and feature extraction methods to study the impact relationship, and OLS regression analysis to study the actual cycle of transformation. We found that: (1) North Korea's grain output is an important indicator that affects its foreign policy tendency (hawks or doves). The hawk refers to those who take a tough attitude in policy and prefer rigid means such as containment, intimidation and conflicts; the dove refers to those who take mild attitude in policy, and prefer to adopt flexible means such as negotiation, cooperation, and coordination. When it comes to grain yield increase, North Korea's foreign policy tends to be hawkish; when it comes to grain reduction, its dovish tendency will be on the rise. This is because food increase can alleviate grain shortage in North Korea and enhance its ability to adopt tough policies in its foreign policy. However, decreases in grain production will lead to adopt a more moderate policy and seek international cooperation and assistance to ease the internal pressure caused by grain shortage. (2) North Korea's grain yield influencing its foreign policy (hawks or doves) has a lag phase of about 3 years. Such being the case, the accumulated grain during the production increase period has enhanced North Korea's ability to cope with grain reduction in the short term. Secondly, the North Korean government blames the reduction on foreign sanctions, which will instead make the North Korean people more determined to resist external pressure. Therefore, we can use the changes in North Korea's grain output to predict the direction of its foreign policy so as to more accurately judge the development of the Korean Peninsula and more effectively promote the process of peace and cooperation in Northeast Asia. We concluded that grain production will affect its policy sustainability in North Korea.
\end{abstract}

Keywords: North Korea; foreign policy; grain output; hawks \& doves 


\section{Introduction}

Changes in a country's foreign policy will often have an impact on its region or even the international community to some degree. It is true that, similar to domestic policies, foreign policies will also be subject to factors such as the domestic political system, political tendency, and characteristics of leadership. However, foreign policies are more sustainable as objective national interests are their common fundamental basis [1]. Therefore, the sustainability of foreign policy refers to the principles, ideas, preferences and other factors that have long-term influence on a country's foreign policy. And countries with an important geographical position in particular, the relationship between the sustainability of their foreign policies and the stability of the regional geopolitical structure is particularly significant [2]. Therefore, measuring and predicting the sustainability of a specific country's foreign policy is not only related to the overall situation of regional political stability, but also of great significance to the sustainability of the development of international relations.

Located in the heart of Northeast Asia, bordered by China and Russia to the north, South Korea to the south, North Korea lies across the seas from Japan and China to the east and west. North Korea is not only a bridge between the mainland and the sea, but also the only way for Northeast Asian countries to realize connectivity. Therefore, its geographical location is of great significance [3]. At the same time, North Korea is also a relatively closed country isolated from the international community for a long time with limited contact with foreign countries. Moreover, its political structure presents the characteristics of "the only leadership system of the top leader" [4-7], in which the personal will and preferences of leaders have great influence on the formulation of national policies [8]. Therefore, it is likely that countries like North Korea will be major variables in this region, directly affecting the sustainability of regional development and a further influence on the liberalization of regional investment and trade.

Certainly, it does not mean that North Korea has no connection with the international community in spite of its relatively closed society. With the development of communication, transportation and information technology, we have seen many economies are inextricably linked to the global economy and the world is gradually becoming a "global village" [9]. Even though North Korea has limited contacts with the outside world, it still has interdependent relations with other countries and the international community. During the Cold War, North Korea relied mainly on socialist countries in its foreign trade, followed by the third world countries, which began to develop trade with western countries except the United States in the 1980s [10]. However, the end of the Cold War and the outbreak of the first North Korean nuclear crisis have sharply worsened the international environment facing North Korea and the foreign aid to the country significantly reduced. In addition, the rigid planned economic system is difficult to transform and the development of domestic industrial structure is unbalanced. Therefore, since the 1990s North Korea has encountered severe economic difficulties and the food shortage is particularly prominent [11]. The main causes of food shortage in North Korea include aging and damaged agricultural infrastructure, frequent natural disasters, serious foreign exchange shortage, sanctions imposed by the international community and adherence to the planned economic system $[12,13]$. At the same time, from the perspective of consumption structure, grain (mainly rice and corn) is still the main source of food consumption in North Korea. Although North Korea has tried to develop alternative food sources by encouraging livestock breeding and developing aquaculture since the late 1990s, the proportion of these substitutes in food consumption is still very low [14].The food problem(Grain output) is the core issue of North Korea's domestic economy, and its influence on North Korea's politics is particularly significant.

Since the 1990s, many scholars on North Korea issues have shifted its focus to the importance of food issues and made unremitting explorations. Their researches mainly cover the following three aspects: First, the assessment of North Korea's food security. Though it is difficult to obtain official statistics, Woon Keun Kim and others have speculated about North Korea's food situation with the data of daily rations of grain per person across North Korea and the experimental data gained in South Korea by simulating the situation of North Korea to estimate the daily consumption and production 
of grain in North Korea respectively. As a result, they draw the conclusion that even in normal conditions, North Korea has serious food deficit of which the median amount can reach $12 \%$ of daily consumption [15,16]. But Randall Ireson holds different opinions. He believes that although the specific data on agricultural production is inaccessible, it is certain that North Korea will gradually achieve self-sufficiency in food with technology and material support [17].

Second, the analysis of North Korean food aid issue. Since the 1990s, the international community, including the United States, Japan, and China, has launched food aid projects out of humanitarian to ease the aggravation of the North Korean food crisis. According to the analysis of its effectiveness made by Stephan Haggard and Marcus Noland, these foods were not given to those in bad demand. Instead, it was transferred to Pyongyang residents and workers in key industries due to the lack of monitoring mechanisms and independent distribution channels. It is estimated that about $30 \%$ of these food is transferred by the North Korean government [18-20]. Li Nan retrospected the history of the United States' aids to North Korea, pointing out that the United States' food aid policy toward the North Korea is full of distinctive political characteristics. The United States aims to take food aid as a means to force North Korea to abandon its nuclear program and to further change its political and social systems. However, the facts have proved that it is difficult for North Korea to make substantive concessions on security, politics, and other issues merely based on food aid [21]. Meanwhile, scholars from South Korea prefer to promote the North-South cooperation with food aid projects. In Kwon Tae-Jin's opinion, such humanitarian acts can create nice environment for cooperation, and then promote the continued cooperation between the two countries in the agricultural field [22].

Third, the impact of the food issue on North Korea's internal affairs. Marcus Noland thinks that food shortage problem plays an important role in triggering North Korea's reform. By then, North Korea has changed some rigid economic systems through adjustments of micro and macroeconomic policies, the establishment of special economic zones, and the search for foreign aids, etc. But he also agrees that these reforms have limited effects as the North Korea's food production has not been restored and its people are still suffering from hungry [4]. Kang Yang-Hee calls North Korea's food problem "food politics" and argues that North Korea has increased public support for the regime by blaming food shortages on external pressures. Even though, Kang says such food policies will expose its limitations in consolidating the people's centripetal power towards the North Korean government with the increase of domestic personnel flow and information exchange in North Korea [23]. While Lim Sang-Cheol paid more attention to the impact of food shortages on North Korean society, including the rise of secret economic activities, the weakening of state control, the disintegration of families, undernourishment of adolescents, and citizens' increasing expectations of foreign countries [24].

The existed researches suggest that although there has been a lot of fruitful researches on the Korean food issue, there are still some shortcomings: first, few discussions focus on the relationship between the food issue and North Korean foreign policy, namely, how will food issue affect North Korea's diplomacy; second, these researches focus more on qualitative study but seldom apply quantitative methods. Therefore, this paper intends to systematically and quantitatively study the impact of food issues on North Korea's foreign policy through three methods: EOF decomposition, wavelet transform, and OLS estimation so that a more accurate judgment on the future foreign policy of North Korea might be made. What needs to be explained here is that although foreign policy is a term in a relatively broader sense, its contents include security policy, economic policy, etc. And the academic circles generally argue that the foreign policy is a clear or ambiguous act beyond the national boundary designed for government officials to promote the national interests, and the priority of this design characterized by integrity and macroscopical meaning constitutes the guidelines for the state to take actions to achieve its goals in a specific situation $[25,26]$. Therefore, the trend of North Korea's foreign policy mentioned in this paper refers to the basic attitude adopted by North Korea in dealing with foreign affairs. 


\section{Model and Method}

\subsection{Data}

Starting from analyzing the grain output data and implementing the scientific criterion of hawk-dove score in a reasonable fashion, the paper aims to study the relationship between grain output and its foreign policy (hawks or doves) in North Korea. First of all, this paper collects the data of North Korea's grain output from 1990 to 2018 through North Korea Statistics Portal of Korea National Statistical Office [27].

In addition, in order to further understand the relationship between grain output and dove-hawk scores based on the fact that North Korea has received a large amount of international food aid, the paper sorts the data on international food aid to North Korea from 1995 to 2012 compiled by the United Nations Food Programme on North Korea in the World website (North Korea only began to receive international aid in 1995, and the statistics of the World Food Programme were interrupted in 2013 and beyond) [28].

Secondly, the author established statistical tables in judging North Korea's foreign policy (hawks or doves) from first arrange the historical events of great significance in North Korea's foreign relations from 1990 to 2018 in a way that we have invited 10 experts and scholars from China, South Korea and the United States in the field of Korean Peninsula to check what they think is of great importance, and made a Chronology of North Korean Foreign Affairs from 1990 to 2018. Then, scores were given by 10 experts on the policy tendency (hawks or doves) of each event and the average score was made to get the hawk-dove scores of North Korea's foreign policy during the period of time.

\subsection{Empirical Orthogonal Function}

Empirical orthogonal function (EOF) is a data reduction analysis method for spatio-temporal data [29-31], the principle of which is to decompose the original data observed $n$ times by $m$ variables into the product of time function and characteristic function according to the principle of variance maximization, thus reflecting the changes of the original data objectively and quantitatively:

$$
X_{m n}=V T
$$

In the solution process, the original panel data is treated as an anomaly, and the eigenvalues and eigenvectors of the symmetric matrix are realistic, and the eigenfunction matrix $V$ is constructed to further calculate the time coefficient matrix $T$ :

$$
T=V^{T} X
$$

And the variance contribution rate $P_{i}$ of the $i$ feature vector and the cumulative variance contribution rate $P_{i}$ of the first $p$ feature vectors are calculated:

$$
\begin{gathered}
\rho_{i}=\lambda / \sum_{i=1}^{m} \lambda_{i} \\
P_{i}=\sum_{i=1}^{p} \lambda_{i} / \sum_{i=1}^{m} \lambda_{i}
\end{gathered}
$$

It can carry out the significant test through calculating the error range of eigenvalues. When the adjacent eigenvalues $\lambda_{j+1}$ and $\lambda_{j}$ satisfy $\lambda_{j+1}-\lambda_{j} \geq \lambda_{j}\left(\frac{2}{n}\right)^{\frac{1}{2}}$, it is considered that the modes corresponding to the two eigenvalues have passed the significance test [32]. 


\subsection{Wavelet Transform}

Wavelet transform is an analysis method of signals based on time-frequency. It can characterize signals in time and frequency domains featuring multi resolution. After the wavelet transform shifts the basic wavelet by $\tau$, it performs an inner product with the analytic signal at different scales $a$ :

$$
W f(a, \tau)=\left\langle f(t), \Psi_{a, \tau}(t)\right\rangle=\frac{1}{\sqrt{a}} \int_{R} \Psi^{*}\left(\frac{t-\tau}{a}\right) d t
$$

This formula, $a>0$, which is called scale factor, is used to expand and contract the basic wavelet $\Psi_{a, \tau}(t) . \tau$ can reflect the displacement. $a$ and $\tau$ are continuous variables. Therefore, it is also called continuous wavelet transform.

Complex Morlet wavelet is a single-frequency complex sine-modulated Gaussian wave, and it is also the most commonly used complex-valued wavelet, of which the time-frequency domain has good locality [33]. Therefore, this paper selects complex Morlet wavelet as the basic wavelet function and calculates it by using matlab2018b. Complex Morlet wavelet can be shown as follow:

$$
\psi(t)=\left(\pi \times f_{b}\right)^{-0.5} e^{2 i \times f_{c} \times t} e^{-t^{2} / f_{b}}
$$

\subsection{Multivariable Linear Regression}

In order to explore the relationship between the policy tendency (hawks or doves) and the food condition, the factors reflecting the grain situation are used as independent variables to explain the changes in the policy tendency, based on which an multivariable linear regression model is established. Multiple linear regression is used to analyze the general relationship between two independent variable $\mathrm{X}$ and dependent variable $\mathrm{Y}$, so as to determine the appropriate mathematical expression.

$$
y=\varepsilon+c x
$$

Note: $\varepsilon$ represents the constant term, and $\mathrm{c}$ is the regression coefficients.

\section{Discussions}

Based on the above calculation results, this paper uses EOF decomposition to further analyze the relationship between North Korea's grain output and its foreign policy orientation. EOF decomposition is a method to extract the feature quantities of main data by using the interrelation among multiple variables to make a few new variables, which are independent of each other and can comprehensively reflect the information of the original multiple variables. EOF decomposes the original data into eigenvectors and time coefficients, and the former represents the characteristics of different variables, while the latter reflects the time variation trend.

The two significant modes can be obtained through EOF decomposition of five variables from 1990 to 2018 including dove-hawk transformation, hawk-dove scores, hawk-dove averages, grain yield and grain price rise and fall, with the cumulative variance contribution rate reaching $99.62 \%$. And the contribution rate of variance of the first mode is $70.43 \%$, which is much larger than that of other modes, indicating that the EOF decomposition result shown to be satisfactory., and the first mode is the main mode reflecting the five types of variables and is tested by North's Rule of Thumb. As shown in Table 1, the characteristic value of grain output is 0.9422 , which is much larger than that of other variables, reflecting the most marked change of grain output from 1990 to 2018. In addition, the characteristic value of the first mode of hawk-dove scores is - 0.3323 , which indicates that the hawk-dove scores has a reverse change with the grain yield in the first mode, and itis slightly lower than the grain yield in the change extent (please refer to Appendix A). 
Table 1. EOF decomposition feature vector.

\begin{tabular}{cccccc}
\hline & $\begin{array}{c}\text { Dove-Hawk } \\
\text { Transformation }\end{array}$ & $\begin{array}{c}\text { Hawk-Dove } \\
\text { Scores }\end{array}$ & $\begin{array}{c}\text { Hawk-Dove } \\
\text { Averages }\end{array}$ & $\begin{array}{c}\text { Grain } \\
\text { Yield }\end{array}$ & $\begin{array}{c}\text { Grain Price } \\
\text { Rise and Fall }\end{array}$ \\
\hline The First Mode & -0.0053 & -0.3323 & -0.0425 & 0.9422 & 0.0071 \\
The Second Mode & 0.0150 & 0.9350 & 0.1153 & 0.3350 & 0.0005 \\
\hline
\end{tabular}

The time coefficient of a certain period is positive, which indicates that the variation of each variable in this period has a distribution similar to the obtained spatial type. If the time coefficient is negative, it is opposite to the obtained spatial type distribution. The larger the absolute value of the time coefficient value, the more typical the distribution pattern is. As can be seen from Figure 1, the first mode coefficient is relatively negative in 1995-1998, 2000 and 2007, which indicates that the grain output fluctuates briefly and violently in negative direction in these years. It is a fact that in 1995, North Korea suffered an unprecedented flood, which destroyed3.2 million hectares of rice and corn fields and lost about 900,000 tons of grain, amounting to 15 billion US dollars [34]. Subsequently, the floods in 1996 and the drought in 1997 further hit North Korea's agriculture, bringing North Korea into an era of so-called "Arduous March" [35]. It was not until 1999 that North Korea's grain output returned to normal in 1994. After entering the 21st century, although the food crisis in North Korea has improved somewhat, the impact of natural disasters on food production is still very great $[36,37]$. In 2007, North Korea once again experienced the worst rainstorm in 40 years, bringing the food quota for urban residents to an all-time low. After 2011, however, the time coefficients of the first mode are all positive, which means that the grain output under this mode has increased steadily. The time coefficient of the first mode shows a fluctuating upward trend, which is mainly due to the fact that North Korea has started to implement field responsibility system of taking on responsibility again since 2012. By allowing private contracted land management on the premise of ensuring sufficient public grain [38], the enthusiasm of farmers and the efficiency of agricultural production have been raised to a certain extent [39]. The time coefficient of the first mode is subjected to wavelet transformation, and the result is shown in Figure 2a. It can be seen that there is a 4a periodic change from 1992 to 1998 , and 4-6a since 1998, of which Figure 3a shows that the period of 6 years is the most significant.

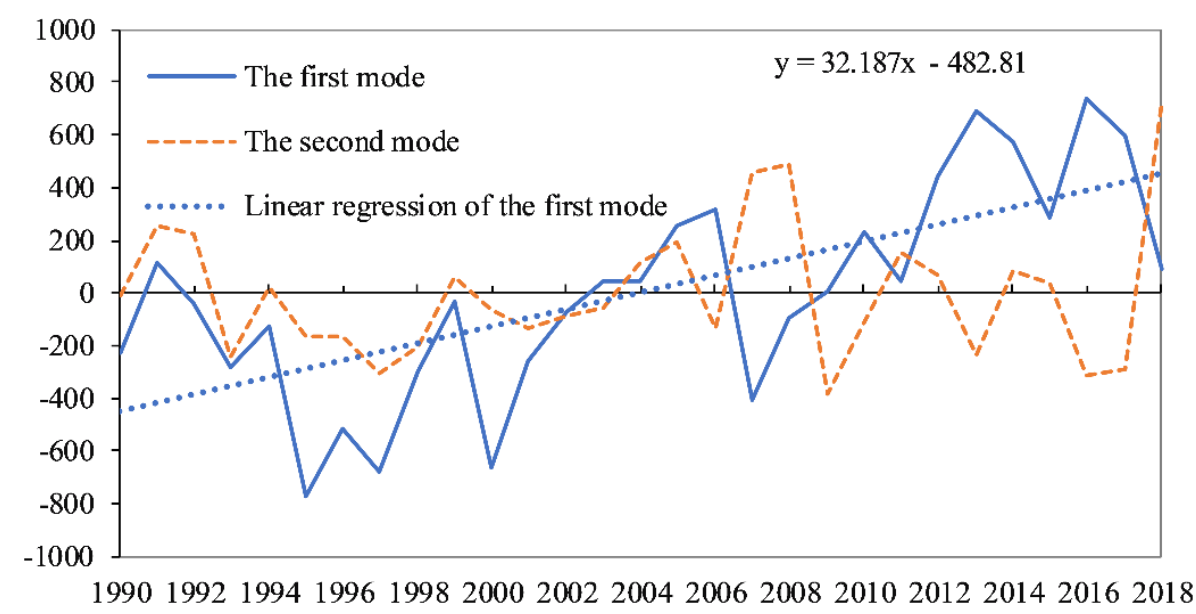

Figure 1. EOF decomposition time coefficient. 
(a) Mode 1
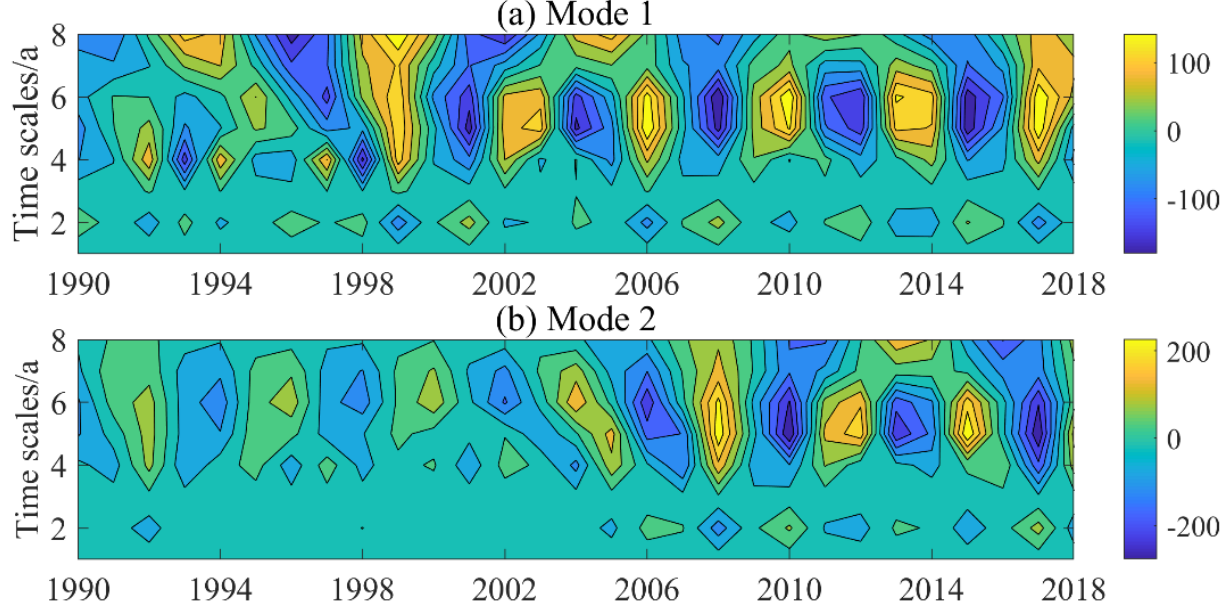

Figure 2. Real contour map of wavelet change.

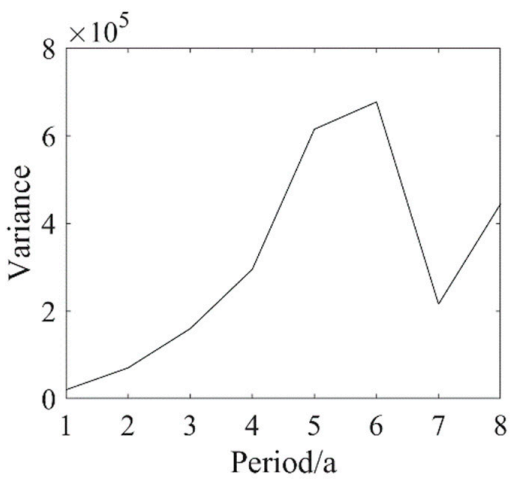

(a) mode 1

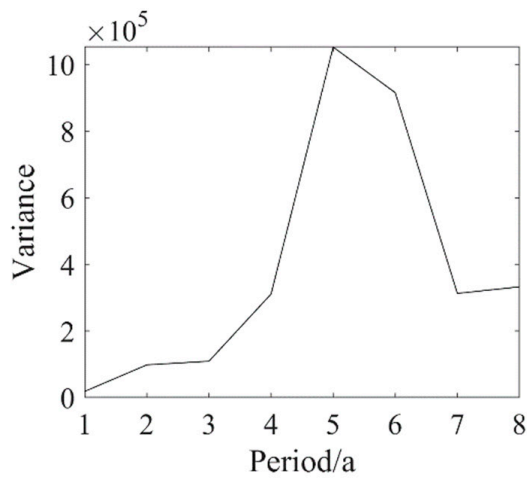

(b) mode 2

Figure 3. Wavelet variance analysis.

The contribution rate of variance of the second mode is $29.19 \%$, and the characteristic value of hawk-dove scores of the second mode in Table 1 is 0.9350 , which is much larger than the grain yield of 0.3350 . Therefore, the second mode is mainly characterized by hawk-dove scores with the grain yield weaker changing with hawk-dove score. From the time coefficient of the second mode in Figure 1, it can be seen that from 1997 to 1998, 2007 to 2008 and in 2018, the grain output and hawk-dove scores showed relatively obvious synchronous growth, which indicates that while North Korea implements a relatively mild foreign policy, the grain is also increasing. According to the statistics of annual grain production in North Korea, turning points of grain production from negative to positive can be seen in the two periods of 1997 1998 and 2007 2008. At the same time, as North Korea was participating in the Four-Party Talks and the Six-Party Talks, it also preferred cooperation to confrontation in its foreign relations [40]. However, there were obvious negative changes in 1993, 1997, 2009, 2013 and in 2016-2017. In terms of grain output, two of the above years have increased production and three have decreased production. However, in terms of foreign policy, with the exception of 1997, North Korea has shown a very strong tendency toward its foreign policy. North Korea announced its withdrawal from Treaty on the Non-Proliferation of Nuclear Weapons for the first time in 1993, and then conducted its second nuclear test and withdrew from the Six-Party Talks in 2009. It conducted the third nuclear test in 2013 and three more nuclear tests in succession from 2016 to 2017, leaving the situation on the peninsula in a state of high tension. There is no obvious trend in the time coefficient of the second mode, but it can be seen from Figure $2 b$ that after 2004, the time coefficient of the second mode has a period of $4 \sim 6$ a years. It can be seen that the period of 5 years is the most significant, followed by 6 years from observing the variance peak of the wavelet analysis in Figure $3 \mathrm{~b}$. 
Due to the obvious synchronous relationship between hawk-dove scores and grain yield shown in EOF decomposition results, there are similar periodic changes, especially after 2004, it is more prominent between hawk-dove scores and grain yield of the synchronization and periodic similarity. Before 2004, the synchronous relationship between the two was not particularly prominent, mainly because the international community's food aid to North Korea weakened the impact of food production on hawk-dove scores. Since North Korea first made a public request for assistance to the international community in 1995, the World Food Programme and the United States, Japan, South Korea and China have all started food aid to North Korea [41]. According to the statistics of the World Food Programme, the amount of international food aid to North Korea remained high until 2005. In 2001, the international community's food aid to North Korea reached its peak, almost three times the amount of aid in 1995 [42]. This is mainly because the western countries led by the United States offering aid hope to intervene North Korea's politics to change the internal situation of North Korea [43,44]. Thanks to the supply of international aid, the food shortage in North Korea has been eased to a large extent, and the pressure of relying on domestic production for food supply has also been partially eased. However, the amount of food aid from the international community to North Korea has dropped significantly after 2005. The peak value of international food aid to North Korea, except for 2007, in other years is less than $70 \%$ of that in 1995, and the lowest value is even over $1 / 10$ of that in 1995 [28]. This situation, on the one hand, is the deterioration of relations between North Korea and the United States and other major donor countries with the food aid linked to North Korea's human rights issues [45], resulting in North Korea's resistance to international aid. But on the other hand, more importantly, North Korea conducted its first nuclear test in 2006, which made the international community began to impose economic sanctions on North Korea and sharply cut its food aid. Therefore, North Korea has to rely more on self-reliance to address food shortage, so the impact of domestic food production on foreign policy (hawks or doves) is highlighted.

In order to further explore the relationship between the policy tendency (hawks or doves) and the food situation, a correlation analysis was made on the influencing factors of the two. At the same time, due to the lack of expression channels of policy needs, the self-interest features of policy subjects, the outdated policies which remained so for the limited rationality of decision makers, and the incapability of decision makers in integration and innovation [46], policies often fail to follow the social trends. Due to the hysteretic nature of the implementation of policy, the three-year average can better reflect the correlation between the hawk-dove index and grain production. According to Paarlberg Robert L's research, it takes some time to show the impact of food production on national policies [47]. And B. Habib's research also shows that food shortages have caused great pressure on North Korea's system, leading to policy changes several years later [48]. And from the regression analysis results, the three-year average has better significance. Therefore, the author calculated the three-year averages of the dove-hawk score and the grain output and the results of the correlation analysis are shown in Table 2.

Table 2. Correlation Analysis between Policy Tendency (Doves or Hawks) and Food Output.

\begin{tabular}{cccc}
\hline & Dove-Hawk Changes & Dove-Hawk Scores & Dove-Hawk Averages \\
\hline Grain Output & $-0.48114^{* * *}$ & $-0.52145^{* *}$ & $-0.36466^{*}$ \\
Grain Output Changes & -0.09399 & -0.23279 & $-0.41347^{* *}$ \\
\hline \multicolumn{2}{c}{${ }^{* * * * *}$ and ${ }^{*}$ represent remarkable decline of significance level at $1 \%, 5 \%$ and $10 \%$ respectively }
\end{tabular}

As can be seen from the values in the Table 2, there is a negative correlation between food output and policy tendency (doves or hawks). The correlation coefficient between the grain output and the dove-hawk score alone exceeds 0.5 , which suggests they have a strong correlation. Therefore, further OLS regression analysis was carried out for grain output and the dove-hawk score.

$$
Y G F S=\varepsilon+c \cdot C L
$$


Here YGFS represents the three- year averages of the dove-hawk score, $C L$ the three-year averages of food output, $c$ the Coefficient variable, $\varepsilon$ the Error term.

Regression result:

As shown in Table 3, the observed value of the F-test statistic is 4.5443 , and the corresponding probability $\mathrm{p}$ is 0.0073 , which is less than 0.01 . Accordingly, there maybe a linear relationship between the dove-hawk score and the grain output. The $t$-test probability $p$ values of $\varepsilon$ and $c_{1}$ are 0.0067 and 0.0073 , both are less than 0.01 . Therefore, the two regression coefficient is significant. The variable grain price rise and fall failed the significance test. Based on that, the linear regression equation can be created as:

$$
\text { YGFS }=2664.9635-0.2073 \cdot C L
$$

Table 3. Regression Statistics of Dove-Hawk Score and Grain Output.

\begin{tabular}{ccccc}
\hline & Coefficient & Std. Error & t-Statistic & Prob. \\
\hline$\varepsilon$ & 2664.9635 & 898.3443 & 2.9665 & 0.0067 \\
$c_{1}$ & -0.2073 & 0.0705 & -2.9293 & 0.0073 \\
$c_{2}$ & -8.9773 & 8.6341 & -1.0397 & 0.3088 \\
\hline
\end{tabular}

From Formula (2), we can know that the grain output coefficient is -0.2073 , namely, for each unit of grain production increase, the dove-hawk score will decrease by 0.2073 , namely, the doves turns to hawkish. This means that increased grain production will make North Korea's foreign policy tougher. It is not difficult to understand. As North Korea suffers from the rigidity of the planned economic system, the sudden changes in the Soviet Union and Eastern Europe [49], as well as the frequent occurrence of natural disasters, its food security has been challenged since the 1990s. Food shortages have caused many instabilities in North Korea, leading to serious social problems [50,51]. In order to solve the food problem, North Korea has to adopt a relatively moderate policy on some foreign affairs, and strive for foreign aids and a good international environment. For example, the convening of the four-party talks in 1997 has a close relationship with the United States' provision of additional food aid to North Korea [52]. However, after the Cold War, the severe imbalance in Northeast Asia's strategic pattern triggered an unprecedented sense of insecurity in North Korea. Obtaining security thus becomes the primary goal of its regime [53]. To realize it, nuclear possession is an important means. Once the food shortage problem and domestic conflicts is settled, North Korea will turn its attention to nuclear weapons construction and take stronger protective action to ensure the security [54]. Therefore, the increase in grain output will ease North Korea and allow North Korea to resist the military pressure and economic sanctions imposed by the United States, South Korea and other countries with a relatively tough attitude.

In addition, from the regression analysis, there is a lag of about 3 years in the impact of grain output on dove-hawk score, namely, it will take about 3 years for policy changes, either the change in the policy from doves to hawks due to increased grain production or the change in policy from hawks to doves caused by reduced grain production, to show off. Because, at the beginning of the reduction of grain production, the previous increase in production will strengthen the government's ability to cope with domestic food shortages in the short term. At the same time, the government may consider the reduction in output as temporary which may soon improve. So, in short term, they don't think it is necessary to adjust policies. Second, the North Korean government often complains domestic economic difficulties on external sanctions and pressures, mobilizes nationalist sentiments. As a result, its citizens would rather insist on their national interests even at the cost of huge punishments [55], adding greater internal pressure to policy adjustment. However, as the reduction in production continues, the growing food gap will cause greater trouble for the government. The shortage of food will also stimulate social contradictions, forcing North Korea to consider adjusting its foreign policy. For example, the two consecutive catastrophes in 1995 and 1996 triggered the Four-Party Talks in 1997 
and the improvement of US-DPRK relations to some extent around the turn of the century [31,56]. From 2010 to 2013, except for a slight reduction in food production in 2011, North Korea had a growing trend in food output. But this growth prompted four consecutive nuclear tests between 2013 and 2017 (so far, North Korea has only conducted a total of 6 nuclear tests).

Positively, since 2018, there have been some signals indicating the increasing possibility of denuclearization in the Korean Peninsula [57]. However, the process of North Korea's nuclear abandonment is full of variables. The U.S. and North Korea still cannot bridge each other especially when some substantive contents become topics of their negotiations [58,59]. As the domestic situation, especially the economy of North Korea is improving, it may resume the confrontation with the United States. Food controls the economy North Korea. According to the above research, North Korea's grain output can have an irreplaceable impact on its foreign policy. Therefore, we can prejudge the future policies that North Korea may adopt in the process of denuclearization based on its food production.

\section{Conclusions}

This paper uses EOF decomposition, wavelet transform and multivariable linear regression to analyze the relationship between North Korea's grain output and its foreign policy from 1990 to 2018 based on North Korea's grain output data and academic experts' scores on North Korea's foreign policy (hawks or doves). The following conclusions are drawn:

1. North Korea's grain output is one of the important indicators to predict its foreign policy tendency towards hawkish or dovish. When grain production increases, North Korea's foreign policy tends to be hawkish. When the grain output is reduced, the dovish tendency of North Korea's foreign policy will rise.

2. Due to the hysteretic nature of the grain output to its foreign policy tendency (hawks or doves), with a lag time of about three years, which means the increase in grain production will give rise to signs of hawkish tendency, while the decrease in grain production will trigger the return of dovish tendency three years later.

3. Currently, the Korean Peninsula is at a very critical moment with its extremely sensitive political situation. The uncertainties have also increased as a result of the impasse of the denuclearization negotiations with the United States. As North Korea's grain output is one of the important indicators for predicting its foreign policy tendency, we can judge the direction of North Korea's foreign policy based on the statistics of grain production, help promote North Korea and the United States to have peaceful negotiations, and effectively promote denuclearization of the Korean Peninsula.

4. North Korea's grain output can be taken as an important reference for predicting the choice of its foreign policy, which is an important determinant of whether Northeast Asia's regional cooperation can proceed smoothly. Therefore, we can use grain output to judge the stability and sustainability of Northeast Asia's regional relations and to advance effective development of economic activities such as trade and investment.

Author Contributions: Conceptualization, G.Y. and C.Z.; methodology, G.Y.; software, G.Y.; validation, J.H., C.Z. and G.Y.; formal analysis, C.Z.; investigation, C.Z.; resources, J.H.; data curation, G.Y.; writing-original draft preparation, C.H.; writing-review and editing, G.H.; visualization, G.Y.; supervision, J.H.; project administration, J.H.; funding acquisition, J.H. All authors have read and agreed to the published version of the manuscript.

Funding: Shanghai Research Center for Students' Safety Education and Shanghai University of Political Science and Law.

Acknowledgments: Thank you very much to Youting Li, from the College of Economics and Management, Shanghai University of Electric Power. Thanks are due to Shuaiwu Li and Hongwei for assistance with the data collection and original draft review.

Conflicts of Interest: The authors declare no conflict of interest. 


\section{Appendix A}

Table A1. North Korea's Grain Output.

\begin{tabular}{lc}
\hline Year & Output (Thousand Tons) \\
\hline $\mathbf{1 9 9 0}$ & 4020 \\
$\mathbf{1 9 9 1}$ & 4427 \\
$\mathbf{1 9 9 2}$ & 4268 \\
$\mathbf{1 9 9 3}$ & 3884 \\
$\mathbf{1 9 9 4}$ & 4125 \\
$\mathbf{1 9 9 5}$ & 3451 \\
$\mathbf{1 9 9 6}$ & 3690 \\
$\mathbf{1 9 9 7}$ & 3489 \\
$\mathbf{1 9 9 8}$ & 3886 \\
$\mathbf{1 9 9 9}$ & 4222 \\
$\mathbf{2 0 0 0}$ & 3590 \\
$\mathbf{2 0 0 1}$ & 3946 \\
$\mathbf{2 0 0 2}$ & 4134 \\
$\mathbf{2 0 0 3}$ & 4253 \\
$\mathbf{2 0 0 4}$ & 4311 \\
$\mathbf{2 0 0 5}$ & 4537 \\
$\mathbf{2 0 0 6}$ & 4484 \\
$\mathbf{2 0 0 7}$ & 4005 \\
$\mathbf{2 0 0 8}$ & 4306 \\
$\mathbf{2 0 0 9}$ & 4108 \\
$\mathbf{2 0 1 0}$ & 4417 \\
$\mathbf{2 0 1 1}$ & 4325 \\
$\mathbf{2 0 1 2}$ & 4676 \\
$\mathbf{2 0 1 3}$ & 4806 \\
$\mathbf{2 0 1 4}$ & 4802 \\
$\mathbf{2 0 1 5}$ & 4512 \\
$\mathbf{2 0 1 6}$ & 4823 \\
$\mathbf{2 0 1 7}$ & 4701 \\
$\mathbf{2 0 1 8}$ & 4558 \\
\hline
\end{tabular}

Table A2. International Food Aid to North Korea (Unit: MT).

\begin{tabular}{cccccccc}
\hline Year & ROK & USA & China & Japan & EU & Other & Total \\
\hline $\mathbf{1 9 9 5}$ & 150,000 & 0 & 0 & 378,000 & 0 & 16,492 & 544,492 \\
$\mathbf{1 9 9 6}$ & 2754 & 22,196 & 100,000 & 137,521 & 0 & 242,728 & 505,199 \\
$\mathbf{1 9 9 7}$ & 60,035 & 192,614 & 150,000 & 640 & 201,112 & 299,180 & 903,581 \\
$\mathbf{1 9 9 8}$ & 48,455 & 231,361 & 151,105 & 67,000 & 103,687 & 188,954 & 790,562 \\
$\mathbf{1 9 9 9}$ & 12,204 & 589,053 & 200,638 & 0 & 68,010 & 130,151 & $1,000,056$ \\
$\mathbf{2 0 0 0}$ & 351,703 & 351,253 & 280,026 & 99,999 & 70,504 & 77,949 & $1,231,434$ \\
$\mathbf{2 0 0 1}$ & 198,000 & 318,729 & 419,834 & 500,000 & 12,595 & 58,800 & $1,507,958$ \\
$\mathbf{2 0 0 2}$ & 457,800 & 222,153 & 329,606 & 0 & 11,606 & 156,946 & $1,178,111$ \\
$\mathbf{2 0 0 3}$ & 542,191 & 46,755 & 212,492 & 0 & 69,185 & 73,781 & 944,404 \\
$\mathbf{2 0 0 4}$ & 406,510 & 105,030 & 132,319 & 80,803 & 10,989 & 109,155 & 844,806 \\
$\mathbf{2 0 0 5}$ & 492,743 & 27,699 & 451,346 & 48,084 & 8450 & 69,001 & $1,097,323$ \\
$\mathbf{2 0 0 6}$ & 79,500 & 0 & 207,251 & 0 & & 20,703 & 307,454 \\
$\mathbf{2 0 0 7}$ & 430,550 & 0 & 264,211 & 0 & 1291 & 24,475 & 720,526 \\
$\mathbf{2 0 0 8}$ & 58,605 & 171,110 & 0 & 0 & 38 & 145,485 & 375,239 \\
$\mathbf{2 0 0 9}$ & 0 & 121,000 & 116,179 & 0 & & 63,485 & 300,664 \\
$\mathbf{2 0 1 0}$ & 22,994 & 1470 & 576 & 0 & & 79,124 & 104,164 \\
$\mathbf{2 0 1 1}$ & 7 & 0 & 2164 & 0 & 1159 & 58,807 & 62,137 \\
$\mathbf{2 0 1 2}$ & & & 240,074 & 0 & 2912 & 129,569 & 372,555 \\
\hline
\end{tabular}


Table A3. 1990-2018 North Korean Great Events and Hawk-Dove Scores.

\begin{tabular}{|c|c|c|c|}
\hline \multirow{2}{*}{ Year } & \multirow{2}{*}{ Events } & \multicolumn{2}{|c|}{$\begin{array}{l}\text { Hawk-Dove Scores } \\
(\text { Dove=D, Hawk }=H)\end{array}$} \\
\hline & & D & $\mathbf{H}$ \\
\hline \multirow[t]{2}{*}{1990} & $\begin{array}{l}\text { Sept.: A delegation headed by former deputy prime minister } \\
\text { Shin Kanemaru, a prominent figure in Liberal Democratic } \\
\text { Party of Japan, met Kim Il Sung three times and issued a } \\
\text { three-party joint statement with the Korean Workers' Party. }\end{array}$ & 10 & 0 \\
\hline & $\begin{array}{l}\text { Sep.4: Premier Yon Hyong-muk of North Korea's Political } \\
\text { Council and South Korean Prime Minister Kang Young-hoon } \\
\text { hold their first premier talks in Seoul. }\end{array}$ & 80 & 0 \\
\hline \multirow{3}{*}{1991} & $\begin{array}{l}\text { Jan.: Negotiations to establish diplomatic relations between } \\
\text { DPRK and Japan starts. }\end{array}$ & 60 & 0 \\
\hline & $\begin{array}{l}\text { Dec.: North Korea and South Korea signed the Inter-Korean } \\
\text { Basic Agreement. }\end{array}$ & 80 & 0 \\
\hline & $\begin{array}{l}\text { Dec.31: North Korea and South Korea signed the Joint } \\
\text { Declaration on the denuclearization of the Korean Peninsula } \\
\text { in Panmunjom. }\end{array}$ & 80 & 0 \\
\hline \multirow{3}{*}{1992} & $\begin{array}{l}\text { Jan: North Korea and International Atomic Energy Agency } \\
\text { signed Nuclear Safety Agreement. }\end{array}$ & 80 & 0 \\
\hline & $\begin{array}{l}\text { Feb.19: During the sixth North-South talks between North } \\
\text { Korea and South Korea, the Prime Ministers of the two } \\
\text { countries respectively read out the Agreement on Reconciliation, } \\
\text { Non-aggression, and Cooperation and Exchange between North and } \\
\text { South and Joint Declaration on the denuclearization of the Korean } \\
\text { Peninsula, which were approved by President Kim Il Sung and } \\
\text { President Roh Tae-woo. }\end{array}$ & 80 & 0 \\
\hline & $\begin{array}{l}\text { Apr.9: The third session of the Ninth Supreme People's } \\
\text { Assembly of North Korea approved the Nuclear Safety } \\
\text { Agreement signed between North Korea and the International } \\
\text { Atomic Energy Agency. }\end{array}$ & 80 & 0 \\
\hline \multirow{2}{*}{1993} & $\begin{array}{l}\text { Mar.: North Korea held a rally with } 100,000 \text { people against } \\
\text { South Korea-US military exercise in Pyongyang. }\end{array}$ & 0 & 30 \\
\hline & $\begin{array}{l}\text { Mar.12: North Korea announced withdrawal from Treaty on the } \\
\text { Non-Proliferation of Nuclear Weapons in } 3 \text { Months. }\end{array}$ & 0 & 70 \\
\hline \multirow{3}{*}{1994} & $\begin{array}{l}\text { Jun.13: North Korea withdrew from International Atomic } \\
\text { Energy Agency. }\end{array}$ & 0 & 70 \\
\hline & $\begin{array}{l}\text { Jun.15-18: Former US President Carter went to Pyongyang to } \\
\text { mediate and reached a Framework agreement on the DPRK } \\
\text { nuclear issue with the North Korean government. }\end{array}$ & 80 & 0 \\
\hline & $\begin{array}{l}\text { Sep.21: North Korea and United States sign Geneva Nuclear } \\
\text { Framework Agreement, and North Korea agrees to freeze } \\
\text { nuclear facilities. }\end{array}$ & 80 & 0 \\
\hline \multirow[t]{2}{*}{1995} & $\begin{array}{l}\text { Mar.: Japan's major parties formed a joint delegation to visit } \\
\text { Pyongyang and jointly signed an agreement with the Korean } \\
\text { Workers' Party on the resumption of diplomatic ties between } \\
\text { Japan and North Korea. }\end{array}$ & 60 & 0 \\
\hline & $\begin{array}{l}\text { Jun.: North Korea has accepted a plan to provide South } \\
\text { Korean light water reactors under the name of the Korean } \\
\text { Peninsula Energy Development Organization. }\end{array}$ & 60 & 0 \\
\hline
\end{tabular}


Table A3. Cont.

\begin{tabular}{|c|c|c|c|}
\hline \multirow[t]{2}{*}{ Year } & \multirow[t]{2}{*}{ Events } & \multicolumn{2}{|c|}{$\begin{array}{l}\text { Hawk-Dove Scores } \\
(\text { Dove=D, Hawk=H) }\end{array}$} \\
\hline & & $\mathbf{D}$ & $\mathbf{H}$ \\
\hline \multirow{3}{*}{1996} & $\begin{array}{l}\text { May.21: Vice Premier of North Korea Hong Song-nam } \\
\text { visits China. }\end{array}$ & 5 & 0 \\
\hline & $\begin{array}{l}\text { Jul.10: Secretary General of the State Council Luo Gan visits } \\
\text { North Korea and Vice Premier Kim Yoon-heok visits China. }\end{array}$ & 5 & 0 \\
\hline & $\begin{array}{l}\text { Dec.29: North Korea has officially issued an official apology on } \\
\text { the infiltration of special forces into South Korea, expressing } \\
\text { deep regret over the incident and stating that it will make } \\
\text { efforts to ensure that such incidents will not happen again. }\end{array}$ & 30 & 0 \\
\hline 1997 & $\begin{array}{l}\text { Feb.: North Korea's senior official Hwang Jang-yop defected } \\
\text { to South Korea via China. Taiwan intends to export nuclear } \\
\text { waste to North Korea, which makes the relations between } \\
\text { China and North Korea tense. North Korea rejected China and } \\
\text { avoided substantive negotiations with China in the } \\
\text { Quadripartite Talks held in August. }\end{array}$ & 0 & 30 \\
\hline 1998 & $\begin{array}{l}\text { Aug.: According to commercial satellite images, the United } \\
\text { States questioned North Korea had hidden underground } \\
\text { nuclear facilities and requested for inspection, which North } \\
\text { Korea firmly denied. North Korea launched the artificial earth } \\
\text { satellite "Kwangmyongsong-1", while the United States } \\
\text { believes it launched the long-range ballistic missile } \\
\text { "Taepodong-1". }\end{array}$ & 0 & 60 \\
\hline \multirow{3}{*}{1999} & $\begin{array}{l}\text { May.25-28: Former U.S. Defense Secretary Perry visited North } \\
\text { Korea as President Clinton's special envoy and had extensive } \\
\text { contacts with North Korean leaders. This is the first time a } \\
\text { senior U.S. official has visited North Korea in } 40 \text { years. }\end{array}$ & 80 & 0 \\
\hline & $\begin{array}{l}\text { Jun.: Kim Yong-nam, chairman of the Standing Committee of } \\
\text { North Korea's Supreme People's Assembly, led a national } \\
\text { delegation to pay an official goodwill visit to China. }\end{array}$ & 5 & 0 \\
\hline & Sept.: Foreign Minister Tang Jiaxuan visits North Korea. & 5 & 0 \\
\hline \multirow{3}{*}{2000} & $\begin{array}{l}\text { Jun.13-15: North Korean leader Kim Jong Il and South Korean } \\
\text { President Kim Dae-jung held a historic meeting in Pyongyang. }\end{array}$ & 90 & 0 \\
\hline & July 19-20: Russian President Putin visits North Korea. & 10 & 0 \\
\hline & Sept.23: Kim Jong Il meets US Secretary of State Albright. & 80 & 0 \\
\hline \multirow[t]{2}{*}{2001} & $\begin{array}{l}\text { Jan.: George Bush took office as President of the United States, } \\
\text { then adjusted his policy towards North Korea, listed North } \\
\text { Korea as an "axis of evil" country and threatened to carry out } \\
\text { a "pre-emptive nuclear strike" against North Korea. }\end{array}$ & 0 & 30 \\
\hline & $\begin{array}{l}\text { Aug.4-5: Kim Jong Il held talks with Russian President Putin } \\
\text { in Moscow and both sides issued North Korea-Russia } \\
\text { Moscow Declaration. }\end{array}$ & 20 & 0 \\
\hline
\end{tabular}


Table A3. Cont.

\begin{tabular}{|c|c|c|c|}
\hline \multirow[t]{2}{*}{ Year } & \multirow[t]{2}{*}{ Events } & \multicolumn{2}{|c|}{$\begin{array}{l}\text { Hawk-Dove Scores } \\
(\text { Dove=D, Hawk }=H)\end{array}$} \\
\hline & & D & $\mathbf{H}$ \\
\hline \multirow{5}{*}{2002} & $\begin{array}{l}\text { Jun.29: North Korea and South Korean warships exchanged } \\
\text { fire in the waters of Yeonpyeong Island in the Yellow Sea. }\end{array}$ & 0 & 50 \\
\hline & $\begin{array}{l}\text { Aug., Kim Jong Il visited Russia again and visited Russia's } \\
\text { Far East. }\end{array}$ & 20 & 0 \\
\hline & $\begin{array}{l}\text { Sept.17: Japanese Prime Minister Junichiro Koizumi visited } \\
\text { North Korea. Leaders of the two sides held talks and issued } \\
\text { the Japan-DPRK Pyongyang Declaration. }\end{array}$ & 80 & 0 \\
\hline & $\begin{array}{l}\text { Sept.3: US President's Special Envoy, Assistant Secretary of } \\
\text { State Jim Kelly, announced that North Korea had "admitted" } \\
\text { its uranium enrichment program after his visit to Pyongyang, } \\
\text { and accused North Korea of developing nuclear weapons. }\end{array}$ & 0 & 30 \\
\hline & $\begin{array}{l}\text { Dec.22: The United States has stopped supplying heavy oil to } \\
\text { North Korea on the grounds that North Korea violated } \\
\text { DPRK-U.S. Nuclear Agreed Framezork. Later, North Korea } \\
\text { announced that it would lift the nuclear freeze, dismantle the } \\
\text { monitoring equipment installed by the International Atomic } \\
\text { Energy Agency in its nuclear facilities and restart the nuclear } \\
\text { facilities used for electricity production. }\end{array}$ & 0 & 50 \\
\hline \multirow{6}{*}{2003} & $\begin{array}{l}\text { Jan.10: North Korea announces its withdrawal from Treaty on } \\
\text { the Non-Proliferation of Nuclear Weapons. }\end{array}$ & 0 & 70 \\
\hline & $\begin{array}{l}\text { Apr.23-25: China, North Korea and the United States held } \\
\text { tripartite talks in Beijing. }\end{array}$ & 10 & 0 \\
\hline & $\begin{array}{l}\text { May.30-Jun.1: US Congressman Delegation visits North Korea. } \\
\text { In talks with North Korea's foreign minister, the United States } \\
\text { asked North Korea to "give up its nuclear program first," } \\
\text { while North Korea asked the United States to change its } \\
\text { hostile policy towards North Korea. }\end{array}$ & 10 & 15 \\
\hline & $\begin{array}{l}\text { Jul.12-15: Deputy Foreign Minister Dai Bingguo visited North } \\
\text { Korea as a special envoy of the Chinese government and held } \\
\text { talks with Kang Sok-ju, the first deputy foreign minister of } \\
\text { North Korea. }\end{array}$ & 5 & 0 \\
\hline & $\begin{array}{l}\text { Aug.27-29: China, North Korea, United States, South Korea, } \\
\text { Russia and Japan hold first round of the Six-Party Talks } \\
\text { in Beijing. }\end{array}$ & 10 & 0 \\
\hline & $\begin{array}{l}\text { Oct.29-31: Wu Bangguo, member of the Standing Committee } \\
\text { of the Political Bureau of the CPC Central Committee and } \\
\text { chairman of the Standing Committee of China's National } \\
\text { People's Congress, led a Chinese national delegation to visit } \\
\text { North Korea. During his visit, he had an in-depth exchange of } \\
\text { views with Kim Jong Il and other North Korean leaders on the } \\
\text { peninsula nuclear issue. }\end{array}$ & 10 & 0 \\
\hline
\end{tabular}


Table A3. Cont.

\begin{tabular}{|c|c|c|c|}
\hline \multirow{2}{*}{ Year } & \multirow{2}{*}{ Events } & \multicolumn{2}{|c|}{$\begin{array}{l}\text { Hawk-Dove Scores } \\
(\text { Dove=D, Hawk=H }\end{array}$} \\
\hline & & D & $\mathbf{H}$ \\
\hline \multirow{3}{*}{2004} & $\begin{array}{l}\text { Feb.25-28: In the second round of the Six-party Talks, North } \\
\text { Korea emphasized that North Korea will abandon its nuclear } \\
\text { program only when the United States abandon its hostile } \\
\text { policy toward North Korea. }\end{array}$ & 10 & 15 \\
\hline & $\begin{array}{l}\text { May.22: North Korean Supreme Leader Kim Jong Il and } \\
\text { Japanese Prime Minister Junichiro Koizumi started talks in } \\
\text { Pyongyang at 11:02 am local time. }\end{array}$ & 60 & 0 \\
\hline & $\begin{array}{l}\text { Jun.23-26: The parties held the third round of the Six-party } \\
\text { Talks. North Korea further clarified its willingness to abandon } \\
\text { nuclear weapons and stated for the first time that it could } \\
\text { openly abandon all nuclear weapons and related plans. }\end{array}$ & 60 & 0 \\
\hline \multirow{4}{*}{2005} & $\begin{array}{l}\text { May.11: North Korea announced the removal of } 8,000 \text { spent } \\
\text { fuel rods from nuclear reactors, restarted a } 5 \mathrm{MW} \text { nuclear } \\
\text { reactor frozen under the framework agreement, and resumed } \\
\text { construction of } 50,000 \mathrm{~kW} \text { and } 200,000 \mathrm{~kW} \text { nuclear reactors. }\end{array}$ & 0 & 50 \\
\hline & $\begin{array}{l}\text { Sept.19: The fourth round of the Six-party Talks worked out a } \\
\text { joint statement. }\end{array}$ & 80 & 0 \\
\hline & $\begin{array}{l}\text { Oct.28-30: At the invitation of Kim Jong Il, then General } \\
\text { Secretary of the Korean Workers Party and Chairman of the } \\
\text { National Defense Committee, Hu Jintao, then General } \\
\text { Secretary of the CPC Central Committee, State President, and } \\
\text { Chairman of the Central Military Commission, visited } \\
\text { North Korea. }\end{array}$ & 10 & 0 \\
\hline & $\begin{array}{l}\text { Nov.9: The first phase of the fifth round of the Six-party Talks } \\
\text { on the North Korean nuclear issue was held in Beijing, } \\
\text { contributing to the guiding Chairman's Statement. }\end{array}$ & 80 & 0 \\
\hline \multirow{6}{*}{2006} & $\begin{array}{l}\text { Jan.10-18: Kim Jong Il paid an informal visit to China, and } \\
\text { visited Hubei, Guangdong, Beijing and other provinces. }\end{array}$ & 20 & 0 \\
\hline & $\begin{array}{l}\text { July.5: North Korea fired the "Taepodong-2", long-range } \\
\text { missile for test. }\end{array}$ & 0 & 60 \\
\hline & $\begin{array}{l}\text { July.16: The North Korea's Ministry of Foreign Affairs issued a } \\
\text { statement, strongly opposing UN Resolution 1695, and stated } \\
\text { that North Korea will not be bound by this resolution. }\end{array}$ & 0 & 50 \\
\hline & $\begin{array}{l}\text { Oct.3: North Korea's Ministry of Foreign Affairs issued a } \\
\text { statement announcing that North Korea would conduct } \\
\text { scientific research on nuclear tests and stressing that North } \\
\text { Korea is still committed to realizing denuclearization of the } \\
\text { Korean Peninsula through dialogue and negotiation. }\end{array}$ & 30 & 50 \\
\hline & $\begin{array}{l}\text { Oct.9: North Korea announced a successful underground } \\
\text { nuclear test. }\end{array}$ & 0 & 100 \\
\hline & $\begin{array}{l}\text { Dec.18-22: The second phase of the fifth round of the } \\
\text { Six-party Talks was held in Beijing. }\end{array}$ & 10 & 0 \\
\hline
\end{tabular}


Table A3. Cont.

\begin{tabular}{|c|c|c|c|}
\hline \multirow[t]{2}{*}{ Year } & \multirow[t]{2}{*}{ Events } & \multicolumn{2}{|c|}{$\begin{array}{c}\text { Hawk-Dove Scores } \\
(\text { Dove=D, Hawk=H) }\end{array}$} \\
\hline & & D & $\mathbf{H}$ \\
\hline \multirow{11}{*}{2007} & $\begin{array}{l}\text { Feb.8-13: The third phase of the fifth round of the } \\
\text { Six-party Talks. }\end{array}$ & 10 & 0 \\
\hline & $\begin{array}{l}\text { Mar.13-14: The Head of the International Atomic Energy } \\
\text { Agency, ElBaradei paid a visit to North Korea. The North } \\
\text { Korea expressed its willingness to cooperate with the } \\
\text { International Atomic Energy Agency to close the Yongbyon } \\
\text { nuclear facility. }\end{array}$ & 60 & 0 \\
\hline & $\begin{array}{l}\text { Mar.19-22: The sixth round of the Six-party Talks was held } \\
\text { in Beijing. }\end{array}$ & 10 & 0 \\
\hline & $\begin{array}{l}\text { Jun.21-22: Hill, the head of the U.S. delegation to the Six-party } \\
\text { Talks on the North Korean nuclear issue and Assistant } \\
\text { Secretary of State, visited North Korea. }\end{array}$ & 60 & 0 \\
\hline & $\begin{array}{l}\text { July.14: After the first batch of } 6,200 \text { tons of heavy oil } \\
\text { delivered by South Korea arrived at North Korea's Sonbong } \\
\text { Port, the North Korea closed the Yongbyon nuclear facility. On } \\
\text { the same day, the inspectors of the International Atomic } \\
\text { Energy Agency returned to North Korea after a lapse of five } \\
\text { years and went to the Yongbyon area to monitor and verify the } \\
\text { closure of nuclear facilities. }\end{array}$ & 70 & 0 \\
\hline & $\begin{array}{l}\text { July.20: The Head of Delegation Meeting of the Sixth Round of } \\
\text { Six-Party Talks drew the curtain in Beijing with a press } \\
\text { communique. The parties reached a four-point framework } \\
\text { consensus on work to do in the next stage and decided a } \\
\text { three-step practice. }\end{array}$ & 80 & 0 \\
\hline & $\begin{array}{l}\text { Sept.1-2: The second round of talks between the US-DPRK } \\
\text { bilateral working groups was held in Geneva, and the two } \\
\text { sides agreed on North Korea's comprehensive declaration of } \\
\text { its nuclear program and the defunctionalization of all } \\
\text { nuclear facilities. }\end{array}$ & 80 & 0 \\
\hline & $\begin{array}{l}\text { Oct. } 2-4 \text { : The second North Korea and South Korea summit } \\
\text { meeting was held. }\end{array}$ & 90 & 0 \\
\hline & $\begin{array}{l}\text { Oct.3: The second phase of the sixth round of the Six-Party } \\
\text { Talks adopted the joint document Implementing the Second } \\
\text { Phase of the Joint Statement. }\end{array}$ & 80 & 0 \\
\hline & $\begin{array}{l}\text { Dec.3-5: US Assistant Secretary of State, head of the US } \\
\text { delegation to the Six-party Talks on the North Korean nuclear } \\
\text { issue, Hill visited North Korea. He inspected the Yongbyon } \\
\text { nuclear facility and discussed North Korea's declaration of } \\
\text { nuclear program with North Korean officials. }\end{array}$ & 70 & 0 \\
\hline & $\begin{array}{l}\text { Dec.14: US President Bush appealed to North Korea in } \\
\text { Washington, asking it to comprehensively declare its nuclear } \\
\text { program and nuclear proliferation. Kim Ge-sik, chief of staff } \\
\text { of the Korean People's Army, said in Pyongyang on the 23rd } \\
\text { that Korean peninsula is still in tense as the United States } \\
\text { continues its war policy. }\end{array}$ & 0 & 20 \\
\hline
\end{tabular}


Table A3. Cont.

\begin{tabular}{|c|c|c|c|}
\hline \multirow[t]{2}{*}{ Year } & \multirow[t]{2}{*}{ Events } & \multicolumn{2}{|c|}{$\begin{array}{l}\text { Hawk-Dove Scores } \\
(\text { Dove=D, Hawk=H) }\end{array}$} \\
\hline & & D & $\mathbf{H}$ \\
\hline \multirow{14}{*}{2008} & \multirow[b]{2}{*}{$\begin{array}{l}\text { Jan.4: The North Korea stressed that they had firmly } \\
\text { implemented the Joint Document Implementation of Joint } \\
\text { Statement Phase II signed in October 13, noticing that the } \\
\text { relevant parties, such as the United States, had not fulfilled the } \\
\text { agreement in a timely manner. They also pointed out that } \\
\text { North Korea should not be responsible for the delay of the } \\
\text { implementation of the Joint Document. }\end{array}$} & 0 & 20 \\
\hline & & 0 & 15 \\
\hline & $\begin{array}{l}\text { Mar.13: the Six-party Talks on the North Korean nuclear issue } \\
\text { were held in Geneva. The heads of the US and North Korean } \\
\text { delegations attended but failed to reach agreement on specific } \\
\text { issues such as North Korea's declaration of a nuclear program. }\end{array}$ & 60 & 0 \\
\hline & $\begin{array}{l}\text { Apr.8: the Six-party Talks on the North Korean nuclear issue } \\
\text { were held in Singapore. The heads of the US and North } \\
\text { Korean delegations attended and agreed on some key issues } \\
\text { in implementing the documents. }\end{array}$ & 60 & 0 \\
\hline & $\begin{array}{l}\text { Apr.22-24: The U.S. working group on North Korea's nuclear } \\
\text { issue visited Pyongyang and discussed with North Korea } \\
\text { specific issues related to the implementation of joint } \\
\text { documents, including issues such as the content of North } \\
\text { Korea's nuclear program declaration. }\end{array}$ & 80 & 0 \\
\hline & $\begin{array}{l}\text { May.8: North Korea submitted North Korean nuclear plan } \\
\text { documents including more than } 18,000 \text { pages. The US } \\
\text { government has taken the move as an "important step" in } \\
\text { verifying North Korea's nuclear program. } \\
\text { In June: Xi Jinping, the member of the Central Politburo } \\
\text { Standing Committee of the CPC and Vice President of China, } \\
\text { visited the North Korea. }\end{array}$ & 5 & 0 \\
\hline & $\begin{array}{l}\text { Jun.10: The U.S. working group on North Korea's nuclear } \\
\text { issue visited Pyongyang for the third time and discussed with } \\
\text { North Korea the technical and transactional issues of the } \\
\text { de-functionalization of North Korea's nuclear facilities, as well } \\
\text { as political and economic compensation by the } \\
\text { parties concerned. }\end{array}$ & 50 & 0 \\
\hline & $\begin{array}{l}\text { Jun.11: The working group on economic and energy } \\
\text { cooperation at the Six-party Talks on the North Korean } \\
\text { nuclear issue held a meeting in Panmunjom. }\end{array}$ & 10 & 0 \\
\hline & $\begin{array}{l}\text { Jun.11-12: North Korea and Japan held intergovernmental } \\
\text { working talks in Beijing. }\end{array}$ & 20 & 0 \\
\hline & $\begin{array}{l}\text { Jun.26: North Korea submitted a declaration on its nuclear } \\
\text { program, and the United States also launched the same day to } \\
\text { remove North Korea from US list of countries that } \\
\text { sponsor terrorism. }\end{array}$ & 80 & 0 \\
\hline & $\begin{array}{l}\text { Jun.27: North Korea blew down cooling towers at its nuclear } \\
\text { facilities in Yongbyon. }\end{array}$ & 80 & 0 \\
\hline & $\begin{array}{l}\text { July.10-12: The head of the delegation of the Six-party Talks on } \\
\text { the North Korean nuclear issue was held in Diaoyutai, Beijing. }\end{array}$ & 10 & 0 \\
\hline & $\begin{array}{l}\text { July.23: The informal meeting of the six foreign ministers on } \\
\text { the North Korean nuclear issue was held in Singapore. }\end{array}$ & 10 & 0 \\
\hline & $\begin{array}{l}\text { Oct.12: North Korea announced the restart of } \\
\text { de-functionalization of nuclear facilities. IAEA investigators } \\
\text { were granted access to the Yongbyon nuclear facility. }\end{array}$ & 80 & 0 \\
\hline
\end{tabular}


Table A3. Cont.

\begin{tabular}{|c|c|c|c|}
\hline \multirow[t]{2}{*}{ Year } & \multirow[t]{2}{*}{ Events } & \multicolumn{2}{|c|}{$\begin{array}{l}\text { Hawk-Dove Scores } \\
(\text { Dove=D, Hawk =H) }\end{array}$} \\
\hline & & D & $\mathbf{H}$ \\
\hline \multirow{11}{*}{2009} & $\begin{array}{l}\text { Jan13: The North Korea's Foreign Ministry stated that North } \\
\text { Korea would only give up its nuclear containment power } \\
\text { when the United States withdraw the nuclear threat to North } \\
\text { Korea and no longer protect South Korea in terms of nuclear. }\end{array}$ & 0 & 30 \\
\hline & $\begin{array}{l}\text { Apr.13: North Korea announced its withdrawal from the } \\
\text { Six-party Talks which focused on the North Korean nuclear } \\
\text { issue and will restore the de-functionalized nuclear facilities as } \\
\text { they were. }\end{array}$ & 0 & 80 \\
\hline & $\begin{array}{l}\text { Apr.5: North Korea announced the successful launch of the } \\
\text { "kwangmyongsong-2", the test communication satellite. } \\
\text { Apr.29: The North Korea's Foreign Ministry stated that if the } \\
\text { UN Security Council does not "apology" for actions that } \\
\text { violate North Korea's autonomy, North Korea will take further } \\
\text { self-defense measures, namely, conduct nuclear tests and } \\
\text { test-fire intercontinental ballistic missiles again. }\end{array}$ & 0 & 60 \\
\hline & $\begin{array}{l}\text { May.8: A spokesman for North Korea's Foreign Ministry said } \\
\text { that North Korea will further strengthen its nuclear } \\
\text { containment in accordance with its stated position because the } \\
\text { US government has no change as before in its policy of } \\
\text { hostility toward North Korea. }\end{array}$ & 0 & 40 \\
\hline & $\begin{array}{l}\text { May.25: North Korea's Central News Agency reported that } \\
\text { North Korea successfully conducted its second underground } \\
\text { nuclear test. }\end{array}$ & 0 & 100 \\
\hline & $\begin{array}{l}\text { Jun.13: North Korea's Ministry of Foreign Affairs was } \\
\text { appointed to express its firm opposition to and condemnation } \\
\text { of UN Security Council } 1874 \text { Resolution on North Korea's } \\
\text { nuclear test, and announced to safeguard national dignity and } \\
\text { national autonomy with three measures if there is a full } \\
\text { confrontation with the United States. }\end{array}$ & 0 & 50 \\
\hline & $\begin{array}{l}\text { July.2: South Korean media quoted military sources, saying } \\
\text { that North Korea had fired four surface-to-ship short-range } \\
\text { missiles in the east coast of North Korea that afternoon } \\
\text { and evening. }\end{array}$ & 0 & 50 \\
\hline & $\begin{array}{l}\text { July.4: According to South Korea's Yonhap News Agency, } \\
\text { North Korea fired } 7 \text { missiles on the eastern sea at a missile } \\
\text { base in Gangwon-do that day. }\end{array}$ & 0 & 50 \\
\hline & $\begin{array}{l}\text { Aug.4: Kim Jong Il welcomed former US President Clinton } \\
\text { in Pyongyang. }\end{array}$ & 80 & 0 \\
\hline & $\begin{array}{l}\text { Aug.5: North Korea published that Kim Jong Il pardoned two } \\
\text { detained US journalists. }\end{array}$ & 70 & 0 \\
\hline & $\begin{array}{l}\text { Sept.4: According to the North Korean Central News Agency, } \\
\text { North Korea has successfully conducted experimental } \\
\text { uranium enrichment, and the test has entered the final stage. }\end{array}$ & 0 & 40 \\
\hline
\end{tabular}


Table A3. Cont.

\begin{tabular}{|c|c|c|c|}
\hline \multirow[t]{2}{*}{ Year } & \multirow[t]{2}{*}{ Events } & \multicolumn{2}{|c|}{$\begin{array}{l}\text { Hawk-Dove Scores } \\
(\text { Dove=D, Hawk }=H)\end{array}$} \\
\hline & & D & $\mathbf{H}$ \\
\hline & $\begin{array}{l}\text { Oct.5: Wen Jiabao, the member of the Central Politburo } \\
\text { Standing Committee of the CPC and Premier of the State } \\
\text { Council, talked with Kim Jong Il, General Secretary of the } \\
\text { Korean Workers Party and Chairman of the National Defense } \\
\text { Committee in Pyongyang, sharing the common goal in } \\
\text { China-DPRK relations and the denuclearization of the Korean } \\
\text { Peninsula. } \\
\text { In December: Bosworth, the U.S. State Department's special } \\
\text { representative for North Korean policy, visited Pyongyang, } \\
\text { marking the first official contacts of the two parties since the } \\
\text { Obama administration took office. }\end{array}$ & 15 & 0 \\
\hline \multirow{8}{*}{2010} & $\begin{array}{l}\text { Jan18: News came from the Korean Central News Agency: a } \\
\text { spokesman for the Ministry of Foreign Affairs of the North } \\
\text { Korea emphasized the necessity to settle the peace agreement } \\
\text { before discussing the denuclearization of the Korean } \\
\text { peninsula, and to abandon sanctions against North Korea } \\
\text { before the Six-Party Talks. }\end{array}$ & 10 & 30 \\
\hline & $\begin{array}{l}\text { Apr.21: The North Korea's Foreign Ministry issued a } \\
\text { memorandum in Pyongyang entitled "Korean Peninsula and } \\
\text { Nuclear Issues", stating that North Korea will participate in } \\
\text { international nuclear disarmament on an equal footing with } \\
\text { other nuclear powers. }\end{array}$ & 20 & 25 \\
\hline & $\begin{array}{l}\text { May.3-7: Kim Jong Il paid an informal visit to China and held } \\
\text { talks with Hu Jintao. }\end{array}$ & 20 & 0 \\
\hline & $\begin{array}{l}\text { On March 26, 2010, the warship "Cheonan" was sunk by a } \\
\text { torpedo attack from the North Korea. Consequently, the North } \\
\text { Korean Peaceful Reunification Commission announced to } \\
\text { server relations with South Korea and imposed sanctions on } \\
\text { South Korea. }\end{array}$ & 0 & 70 \\
\hline & $\begin{array}{l}\text { In July: North Korea and US held high-level talks in } \\
\text { Bali, Indonesia. }\end{array}$ & 10 & 0 \\
\hline & $\begin{array}{l}\text { Sept.29: North Korean Deputy Foreign Minister Park Ji-yeon } \\
\text { said in a general debate at the UN General Assembly that } \\
\text { North Korea will not give up its nuclear deterrence as long as } \\
\text { the United States does not stop using its mailed fist. }\end{array}$ & 0 & 30 \\
\hline & $\begin{array}{l}\text { In October: North Korea and the United States held high-level } \\
\text { talks in Geneva, Switzerland. }\end{array}$ & 10 & 0 \\
\hline & $\begin{array}{l}\text { Nov.23: South Korea fired dozens of artillery shells into the } \\
\text { disputed waters of the North and South during its annual } \\
\text { military exercise. To respond it, North Korea immediately } \\
\text { shelled South Korea's Yeonpeong Island artillery position. }\end{array}$ & 0 & 70 \\
\hline
\end{tabular}


Table A3. Cont.

\begin{tabular}{|c|c|c|c|}
\hline \multirow[t]{2}{*}{ Year } & \multirow[t]{2}{*}{ Events } & \multicolumn{2}{|c|}{$\begin{array}{l}\text { Hawk-Dove Scores } \\
(\text { Dove=D, Hawk }=H)\end{array}$} \\
\hline & & D & $\mathbf{H}$ \\
\hline \multirow{6}{*}{2011} & $\begin{array}{l}\text { Mar.15: A spokesman for North Korea's Foreign Ministry said } \\
\text { in Pyongyang that North Korea would participate } \\
\text { unconditionally in the Six-Party Talks on the North Korean } \\
\text { nuclear issue and has no objection to discussing uranium } \\
\text { enrichment during the Six-Party Talks. }\end{array}$ & 50 & 0 \\
\hline & $\begin{array}{l}\text { July: At the invitation of the North Korean government, } \\
\text { Zhang Dejiang, then member of the Political Bureau of the } \\
\text { CPC Central Committee and vice premier of the State Council, } \\
\text { led a Chinese delegation to visit the North Korea to celebrate } \\
\text { the } 50^{\text {th }} \text { anniversary of the signing of the Treaty of Friendship } \\
\text { Cooperation and Mutual Assistance between the people's Republic of } \\
\text { China and the Democratic people's Repulic of Korea. }\end{array}$ & 5 & 0 \\
\hline & $\begin{array}{l}\text { July.28-29: Kim Kye-gwan, First Deputy Prime Minister of the } \\
\text { Ministry of Foreign Affairs of the North Korea, was invited to } \\
\text { visit the United States to talk with the US Envoy for North } \\
\text { Korea, Stephen Bosworth, on the resumption of the Six-Party } \\
\text { Talks on the North Korean nuclear issue. This is the first } \\
\text { high-level dialogue between the two sides since } 2009 \text {. }\end{array}$ & 60 & 0 \\
\hline & $\begin{array}{l}\text { Aug.24: Russian President Dmitri Anatolyevich Medvedev } \\
\text { held talks with Kim Jong Il, chairman of the North Korean } \\
\text { Defense Council, in Russia. Kim Jong Il informed Medvedev } \\
\text { during the talks that North Korea was ready to return } \\
\text { unconditionally to the Six-Party Talks and to stop producing } \\
\text { nuclear materials and conducting nuclear tests during } \\
\text { the negotiations. }\end{array}$ & 20 & 0 \\
\hline & $\begin{array}{l}\text { October: Li Keqiang, then the member of the Central Politburo } \\
\text { Standing Committee of the CPC and Vice Premier of the State } \\
\text { Council, visited North Korea. }\end{array}$ & 5 & 0 \\
\hline & $\begin{array}{l}\text { Oct.24: The United States and North Korea representatives } \\
\text { held a two-day talk in Geneva, Switzerland on the resumption } \\
\text { of the Six-Party Talks on the North Korean nuclear issue. }\end{array}$ & 10 & 0 \\
\hline \multirow{4}{*}{2012} & $\begin{array}{l}\text { Feb.23-29: The third high-level talks between the North Korea } \\
\text { and the United States were held in Beijing. As a result, the } \\
\text { Leap Day agreement based on "freezing nucleus for } \\
\text { compensation" was reached. }\end{array}$ & 70 & 0 \\
\hline & $\begin{array}{l}\text { April: North Korea wrote "nuclear possession" into } \\
\text { its Constitution. }\end{array}$ & 0 & 40 \\
\hline & $\begin{array}{l}\text { Apr.13: According to the Korean Central News Agency, North } \\
\text { Korea launched the first application satellite } \\
\text { "Kwangmyongsong-3" that morning. Later, the US } \\
\text { government announced that it would abandon its previous } \\
\text { food aid agreement with North Korea. }\end{array}$ & 0 & 60 \\
\hline & $\begin{array}{l}\text { July.20: A spokesman for North Korea's Ministry of Foreign } \\
\text { Affairs stated that North Korea had to reconsider the nuclear } \\
\text { issue" as the United States did not change its hostile policy. }\end{array}$ & 0 & 30 \\
\hline
\end{tabular}


Table A3. Cont.

\begin{tabular}{|c|c|c|c|}
\hline \multirow[t]{2}{*}{ Year } & \multirow[t]{2}{*}{ Events } & \multicolumn{2}{|c|}{$\begin{array}{c}\text { Hawk-Dove Scores } \\
(\text { Dove=D, Hawk=H) }\end{array}$} \\
\hline & & $\mathbf{D}$ & $\mathbf{H}$ \\
\hline \multirow{6}{*}{2013} & $\begin{array}{l}\text { Feb.12: North Korea successfully conducted its third } \\
\text { underground nuclear test. }\end{array}$ & 0 & 100 \\
\hline & $\begin{array}{l}\text { Mar.13: North Korea suspended the North Korean Armistice } \\
\text { Agreement signed in } 1953 \text { and declared that it is no longer } \\
\text { bound by the non-aggression treaty. }\end{array}$ & 0 & 80 \\
\hline & $\begin{array}{l}\text { March: The route "nuclear weapons and economy advance } \\
\text { together" was settled. }\end{array}$ & 0 & 40 \\
\hline & $\begin{array}{l}\text { Apr.2: A spokesperson for the North Korean General } \\
\text { Administration of Atomic Energy stated that North Korea } \\
\text { would restart the } 5 \mathrm{MW} \text { graphite deceleration reactor in } \\
\text { Yongbyon, which had been closed in } 2007 \text {. }\end{array}$ & 0 & 50 \\
\hline & $\begin{array}{l}\text { Apr.3: North Korea closed the Kaesong industrial area which } \\
\text { was established in cooperation with South Korea. At the } \\
\text { meantime, South Koreans were asked to leave. }\end{array}$ & 0 & 50 \\
\hline & $\begin{array}{l}\text { May.18: North Korea fired a total of } 4 \text { short-range missiles into } \\
\text { the Sea of Japan. } \\
\text { Aug.10: North and South Korea again shelled near the } \\
\text { northern border. }\end{array}$ & 0 & 50 \\
\hline \multirow{4}{*}{2014} & Jun.26-29: North Korea conducted at least 4 missile tests. & 0 & 50 \\
\hline & $\begin{array}{l}\text { Oct.4: North Korea dispatched Hwang Pyong-so and other } \\
\text { senior officials to attend the closing ceremony of the Asian } \\
\text { Games in Incheon. }\end{array}$ & 50 & 0 \\
\hline & $\begin{array}{l}\text { Oct.7: North Korean and Korean Navy patrol boats began to } \\
\text { fight with each other. }\end{array}$ & 0 & 50 \\
\hline & $\begin{array}{l}\text { Nov.20: A spokesman for the Ministry of Foreign Affairs of } \\
\text { North Korea issued a statement saying that what the United } \\
\text { States are doing is actually forcing North Korea to continue a } \\
\text { new round of nuclear tests. }\end{array}$ & 0 & 40 \\
\hline \multirow{4}{*}{2015} & $\begin{array}{l}\text { May.20: A spokesperson for the Policy Bureau of the North } \\
\text { Korean Defense Council stated that North Korea's nuclear } \\
\text { strike means have become miniaturized and diversified and } \\
\text { warned all parties that these are North Korea's inviolable } \\
\text { measures to strengthen its self-defense capabilities. }\end{array}$ & 0 & 30 \\
\hline & $\begin{array}{l}\text { July.21: North Korea noted that it would not resolve the } \\
\text { nuclear issue on the Korean peninsula as The Iranian nuclear } \\
\text { deal, saying "North Korea will never give up } \\
\text { nuclear weapons." }\end{array}$ & 0 & 40 \\
\hline & $\begin{array}{l}\text { Aug.25: North Korea and South Korea reached the "Aug.25 } \\
\text { Agreement". The two sides agreed on a number of issues } \\
\text { including holding inter-governmental talks between the North } \\
\text { and the South Korea, releasing the quasi-wartime status of the } \\
\text { North Korea, and realizing reunion of separated families of } \\
\text { North and South Korea. }\end{array}$ & 60 & 0 \\
\hline & $\begin{array}{l}\text { Sept.15: North Korea suggested that Yongbyon's nuclear } \\
\text { facility began to operate at "full capacity". }\end{array}$ & 0 & 30 \\
\hline
\end{tabular}


Table A3. Cont.

\begin{tabular}{|c|c|c|c|}
\hline \multirow[t]{2}{*}{ Year } & \multirow[t]{2}{*}{ Events } & \multicolumn{2}{|c|}{$\begin{array}{l}\text { Hawk-Dove Scores } \\
(\text { Dove=D, Hawk=H) }\end{array}$} \\
\hline & & $\mathbf{D}$ & $\mathbf{H}$ \\
\hline \multirow{8}{*}{2016} & $\begin{array}{l}\text { Jan.6: North Korea announced that it successfully conducted } \\
\text { its first hydrogen bomb test (the fourth nuclear test). }\end{array}$ & 0 & 100 \\
\hline & $\begin{array}{l}\text { Feb.7: North Korea announced the launch of the } \\
\text { "Kwangmyongsong-4" satellite with a long-range rocket. }\end{array}$ & 0 & 60 \\
\hline & $\begin{array}{l}\text { Mar.10: The North Korean Unified Peace Commission } \\
\text { declared all economic cooperation and exchange agreements } \\
\text { between the North and South Korea invalid and fired two } \\
\text { "Scud" missiles. }\end{array}$ & 0 & 60 \\
\hline & $\begin{array}{l}\text { July-August: North Korea fired several missiles with a range } \\
\text { of } 500 \text { kilometers into the eastern waters of the peninsula. }\end{array}$ & 0 & 50 \\
\hline & $\begin{array}{l}\text { Aug.18: The Ministry of Foreign Affairs of North Korea } \\
\text { suggested that the situation on the Korean Peninsula has } \\
\text { entered an "extremely dangerous stage". If the United States } \\
\text { dares to take "mad measures", Pyongyang will destroy all US } \\
\text { military bases in the Pacific. }\end{array}$ & 0 & 40 \\
\hline & $\begin{array}{l}\text { Aug.24: North Korea fired a submarine-launched ballistic } \\
\text { missile into the eastern waters of the Korean Peninsula. }\end{array}$ & 0 & 50 \\
\hline & Sept.5: North Korea fired another three ballistic missiles at sea. & 0 & 50 \\
\hline & $\begin{array}{l}\text { Sept.9: North Korea's CCTV reported that North Korea } \\
\text { successfully conducted a nuclear test that day. }\end{array}$ & 0 & 100 \\
\hline \multirow{6}{*}{2017} & $\begin{array}{l}\text { Feb.12: North Korea fired a ballistic missile from the } \\
\text { northwest of the country to the east. }\end{array}$ & 0 & 50 \\
\hline & $\begin{array}{l}\text { Feb.13: Kim Jong-nam was assassinated. Diplomatic disputes } \\
\text { broke out between North Korea and Malaysia. }\end{array}$ & 0 & 30 \\
\hline & $\begin{array}{l}\text { May.14: North Korea launched "Hwasong-12" long-range } \\
\text { ballistic missile. }\end{array}$ & 0 & 80 \\
\hline & $\begin{array}{l}\text { July.3: North Korea fired a "Hwasong-14" intercontinental } \\
\text { ballistic rocket for adjustment. }\end{array}$ & 0 & 90 \\
\hline & $\begin{array}{l}\text { Sept.3: North Korea conducted its sixth nuclear test at the } \\
\text { Punggye-ri nuclear test site in Kilju County, North } \\
\text { Hamgyong Province. }\end{array}$ & 0 & 100 \\
\hline & $\begin{array}{l}\text { Nov.29: North Korea fired the "Hwasong-15" intercontinental } \\
\text { ballistic missile for adjustment. }\end{array}$ & 0 & 90 \\
\hline \multirow[b]{3}{*}{2018} & $\begin{array}{l}\text { Feb.9: A high-level delegation from North Korea visited South } \\
\text { Korea and attended the opening ceremony of the The } 2018 \\
\text { Winter Olympics in Pyeongchang. }\end{array}$ & 60 & 0 \\
\hline & Mar.25-28: Kim Jong Un paid informal visits to China. & 20 & 0 \\
\hline & $\begin{array}{l}\text { Apr.20: The Third Plenary Session of the Seventh Central } \\
\text { Committee of the Korean Workers Party decided to suspend } \\
\text { nuclear tests and intercontinental ballistic missile test launches } \\
\text { from October } 8,2017 \text {, abandon the northern nuclear test site, } \\
\text { and shift the overall cause of the party and the country to } \\
\text { socialist economic construction. }\end{array}$ & 60 & 0 \\
\hline
\end{tabular}


Table A3. Cont.

\begin{tabular}{|c|c|c|c|}
\hline \multirow[t]{2}{*}{ Year } & \multirow[t]{2}{*}{ Events } & \multicolumn{2}{|c|}{$\begin{array}{l}\text { Hawk-Dove Scores } \\
(\text { Dove=D, Hawk=H) }\end{array}$} \\
\hline & & $\mathbf{D}$ & $\mathbf{H}$ \\
\hline & $\begin{array}{l}\text { Apr.27: South Korean President Moon Jae-in and North } \\
\text { Korea's top leader Kim Jong-un held their first meeting at the } \\
\text { "Peace House" of Panmunjom (on the Korean side). They } \\
\text { signed the the Panmunjom Declaration for Peace, Prosperity and } \\
\text { Unification of the Korean Peninsula, announcing that the two } \\
\text { parties will work hard to realize the denuclearization and turn } \\
\text { the armistice agreement into a peace treaty. }\end{array}$ & 90 & 0 \\
\hline & May.7-8: Xi Jinping and Kim Jong Un meet in Dalian & 20 & 0 \\
\hline & $\begin{array}{l}\text { May.24: North Korea blasted a number of tunnels and } \\
\text { ancillary facilities at the Punggye-ri nuclear test site in Kilju } \\
\text { County, North Hamgyong Province, and announced that the } \\
\text { nuclear test site was officially abandoned. }\end{array}$ & 70 & 0 \\
\hline & $\begin{array}{l}\text { May.26: South Korean President Moon Jae-in and North } \\
\text { Korea's top leader Kim Jong-un held their second meeting. }\end{array}$ & 90 & 0 \\
\hline & $\begin{array}{l}\text { Jun.12: The first meeting of US and North Korean leaders was } \\
\text { held in Singapore. }\end{array}$ & 100 & 0 \\
\hline & Jun.19-20: Kim Jong Un visited China. & 20 & 0 \\
\hline & $\begin{array}{l}\text { Sept.18-20: South Korean President Moon Jae-in and } \\
\text { Chairman of the State Council of Korea Kim Jong-un hold the } \\
\text { third meeting. }\end{array}$ & 90 & 0 \\
\hline & $\begin{array}{l}\text { Dec.26: The commencement ceremony of the Korean railway } \\
\text { and highway docking project. }\end{array}$ & 50 & 0 \\
\hline
\end{tabular}

\section{References}

1. Song, W. How to United Diplomacy and Domestic Affairs: A Perspective of Positional Realism. Q. J. Int. Polit. 2018, 4, 31-53.

2. Cho, M.H. Korean unification studies series, 7. In Korea and the Major Powers: An Analysis of Power Structures in East Asia; Research Center for Peace and Unification of Korea: Seoul, Korea, 1989.

3. Pinto, V. Nuclear North Korea: Politics of Six-Way Talks. Econ. Polit. Wkly. 2007, 42, 741-742.

4. Noland, M. Famine and reform in North Korea. Asian Econ. Pap. 2004, 3, 1-40. [CrossRef]

5. Li, Y.; Yang, W.; Shen, X.; Yuan, G.; Wang, J. Water Environment Management and Performance Evaluation in Central China: A Research Based on Comprehensive Evaluation System. Water 2019, 11, 2472. [CrossRef]

6. Yang, W.; Yuan, G.; Han, J. Is China's air pollution control policy effective? Evidence from Yangtze River Delta cities. J. Clean. Prod. 2019, 220, 110-133. [CrossRef]

7. Yang, Y.; Yang, W. Does Whistleblowing Work for Air Pollution Control in China? A Study Based on Three-party Evolutionary Game Model under Incomplete Information. Sustainability 2019, 11, 324. [CrossRef]

8. Steven, E.L.; Norrin, M.R.; Jeffery, W.T. Neoclassical Realism, the State, and the Foreign Policy; Cambridge University Press: London, UK, 2009.

9. Burton, D.F. The Brave New Wired World. Foreign Policy 1997, 106, 22-37. [CrossRef]

10. Jeong, K. A Study on North Korean Foreign Trade Structure. World Reg. Stud. 1995, 1, 105.

11. Goldstein, L.J. The Great North Korean Famine: Famine, Politics, and Foreign Policy. Nav. War Coll. Rev. 2002, 55, 9 .

12. Quan, Z.; Xing, H. Food Shortages in the DPRK and Prospects for a Solution. Contemp. Int. Relat. $2013,2,9$.

13. Hong, J. An Analysis of North Korean Food Problem. Eurasian Obs. 2000, 3, 29-30.

14. Ma, D. An Review of North Korean Food Problem. Int. Inf. 2007, 12, 8. 
15. Shen, X.; Yang, W.; Sun, S. Analysis of the Impact of China's Hierarchical Medical System and Online Appointment Diagnosis System on the Sustainable Development of Public Health: A Case Study of Shanghai. Sustainability 2019, 11, 6564. [CrossRef]

16. Kim, W.K.; Lee, H.; Sumner, D.A. Assessing the Food Situation in North Korea. Econ. Dev. Cult. Chang. 1998, 46, 519-535. [CrossRef]

17. Ireson, R. Food Security in North Korea: Designing Realistic Possibilities; The Walter H. Shorenstein Asia-Pacific Research Center, Stanford University: Stanford, CA, USA, 2006.

18. Haggard, S.; Noland, M. Famine in North Korea: Markets, Aid, and Reform; Columbia University Press: New York, NY, USA, 2007.

19. Yuan, G.; Yang, W. Evaluating China's Air Pollution Control Policy with Extended AQI Indicator System: Example of the Beijing-Tianjin-Hebei Region. Sustainability 2019, 11, 939. [CrossRef]

20. Li, L.; Yang, W. Total Factor Efficiency Study on China's Industrial Coal Input and Wastewater Control with Dual Target Variables. Sustainability 2018, 10, 2121. [CrossRef]

21. Li, N. Evolution and Assessment of U.S. Food Aid towards DPRK. Chin. J. Am. Stud. 2014, 28, 24.

22. Taejin, K. North Korea's Food Demand and Its Cooperation Plan. Korean J. Unific. Econ. 2010, 14, 12.

23. Kang, Y. The Food Politics for Supporting North Korea's Continuation of Regime. Korean J. Unific. Aff. 2012, $24,1$.

24. Lim, S. Causes of Food Shortage in North Korea and Its Impact on North Korean Society. Policy Sci. Stud. 2008, 18, 56 .

25. Amstutz, M.R. International Conflict and Cooperation: An Introduction to World Politics; McGraw-Hill College: Boston, MA, USA, 1999.

26. Pearson, F.S.; Rochester, J.M. International Relations; McGraw-Hill: New York, NY, USA, 1998.

27. Korea Bureau of Statistics. North Korea Statistics. Available online: http://kosis.kr/bukhan/index.jsp (accessed on 10 March 2020).

28. The East-West Center; The National Committee on North Korea. North Korea in the World. Available online: https://www.northkoreaintheworld.org/humanitarian/food-assistance (accessed on 10 March 2020).

29. Yang, W.; Li, L. Efficiency Evaluation and Policy Analysis of Industrial Wastewater Control in China. Energies 2017, 10, 1201. [CrossRef]

30. Gao, H.; Yang, W.; Yang, Y.; Yuan, G. Analysis of the Air Quality and the Effect of Governance Policies in China's Pearl River Delta, 2015-2018. Atmosphere 2019, 10, 412. [CrossRef]

31. Yuan, G.; Yang, W. Study on optimization of economic dispatching of electric power system based on Hybrid Intelligent Algorithms (PSO and AFSA). Energy 2019, 183, 926-935. [CrossRef]

32. North, G.; Bell, T.; Cahalan, R.; Moeng, F. Sampling Errors in the Estimation of Empirical Orthogonal Functions. Mon. Weather Rev. 1982, 110, 699-706. [CrossRef]

33. Yang, W.; Li, L. Energy Efficiency, Ownership Structure, and Sustainable Development: Evidence from China. Sustainability 2017, 9, 912. [CrossRef]

34. Gong, Y. An Analysis of Agricultural Reform in North Korea. Contemp. Asia-Pac. Stud. 2007, 6, 51.

35. Noland, M. A Nuclear North Korea: Where Do We Go From Here? Straits Times 2006, 10, 11.

36. World Food Programme of United Nations. Emergency Operation Democratic People's Republic of Korea: 10757.0_Emergency Assistance to Population Groups Affected by Floods and Rising Food and Fuel Prices; World Food Programme of United Nations: New York, NY, USA, 2008.

37. Yang, W.; Yang, Y. Research on Air Pollution Control in China: From the Perspective of Quadrilateral Evolutionary Games. Sustainability 2020, 12, 1756. [CrossRef]

38. Jeong, J. A Study on the Changing of North Korea Agricultural Policy and Cooperation. Econ. Stud. Korean Peasant Assoc. 2018, 48, 53.

39. Li, S.; Quan, Z. An Analysis of Agricultural Reform of DPRK. Dongjiang J. 2016, 33, 61.

40. Sanger, D.E. Nuclear Pact Broadening, North Korea and U.S. Say. Available online: https://www.nytimes. com/2007/09/03/world/asia/03nkorea.html (accessed on 10 March 2020).

41. Min, T.J. Food Shortage in North Korea: Humanitarian Aid Versus Policy Objectives. Hum. Rights Br. 1996, 4,7 .

42. World Food Programme of United Nations. Democratic People's Republic of Korea. Available online: https://www.wfp.org/countries/democratic-peoples-republic-korea (accessed on 10 March 2020).

43. Harrison, S.S. Time to leave Korea? Foreign Aff. 2001, 80, 62-78. [CrossRef] 
44. Yang, W.; Li, L. Analysis of Total Factor Efficiency of Water Resource and Energy in China: A Study Based on DEA-SBM Model. Sustainability 2017, 9, 1316. [CrossRef]

45. Chang, S. The North Korean Human Rights Act of 2004. North Korean Rev. 2006, 2, 80-88. [CrossRef]

46. Charles, E.L.; Woodhouse, E.J. The Policy-Making Process; Prentice-Hall: Englewood Cliffs, NJ, USA, 1968.

47. Paarlberg, R. Food Politics: What Everyone Needs to Know; Oxford University Press: Oxford, UK, 2013.

48. Habib, B. Another Perfect Storm? Predictors of Radical Change in North Korea. Secur. Chall. 2008, 4, $21-41$.

49. Smith, H.; Huang, Y. Achieving Food Security in North Korea. In Promoting International Scientific, Technological and Economic Cooperation in the Korean Peninsula: Enhancing Stability and International Dialogue; Istituto Diplomatico Mario Toscano; The Italian Ministry of Foreign Affairs: Rome, Italy, 2000.

50. Habib, B. Climate change and the terminal decay of the North Korean regime. In Proceedings of the 3rd Biennial Oceanic Conference on “International Studies”, Brisbane, Australia, 1-4 July 2008.

51. Yang, W.; Li, L. Efficiency evaluation of industrial waste gas control in China: A study based on data envelopment analysis (DEA) model. J. Clean. Prod. 2018, 179, 1-11. [CrossRef]

52. Kang, J. Policy Dilemma: Food Aid to all Enemy State. Int. Stud. Rev. 2005, 345, 22.

53. Eberstadt, N. Hastening Korean Reunification. Foreign Aff. 1997, 76, 77-92. [CrossRef]

54. Choe, S. North Korea Vows to Keep Nuclear Arms and Fix Economy. Available online: https://www.nytimes. com/2013/04/01/world/asia/north-korea-vows-to-keep-nuclear-arms-and-fix-economy.html (accessed on 10 March 2020).

55. Pape, R.A. Why Economic Sanctions Do Not Work. Int. Secur. 1997, 22, 90-136. [CrossRef]

56. Wang, W. A Study on China-DPRK Relations under the Nuclear Shadow; Sinseong Press: Seoul, Korea, 2017.

57. Kim, L. South Korea's Nuclear Hedging? Wash. Q. 2018, 41, 115-133. [CrossRef]

58. Anderson, N.D. Explaining North Korea's Nuclear Ambitions: Power and Position on the Korean Peninsula. Aust. J. Int. Aff. 2017, 71, 621-641. [CrossRef]

59. Toby, D.; Ariel, L. When Trump Meets Kim Jong Un: A Realistic Option for Negotiating With North Korea. Available online: https://carnegieendowment.org/2018/03/26/when-trump-meets-kim-jong-un-realisticoption-for-negotiating-with-north-korea-pub-75898 (accessed on 10 March 2020).

(C) 2020 by the authors. Licensee MDPI, Basel, Switzerland. This article is an open access article distributed under the terms and conditions of the Creative Commons Attribution (CC BY) license (http://creativecommons.org/licenses/by/4.0/). 